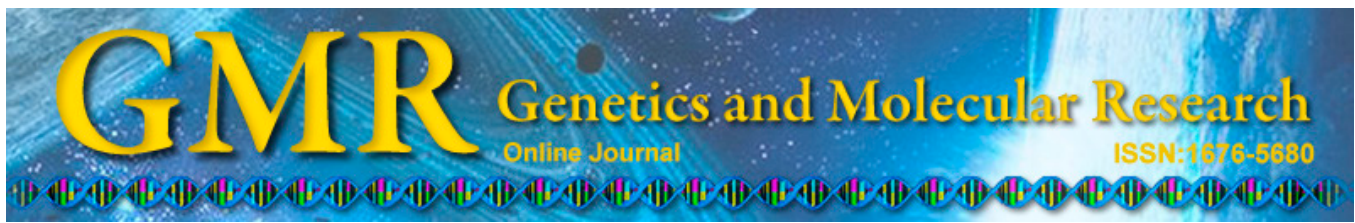

\title{
Genetic and biogeographical relationships among species of Astyanax (Teleostei, Characidae) in Brazilian river basins
}

\author{
R. Mello ${ }^{1,2}$, T.C. Maniglia ${ }^{3}$, S.M.A.P. Prioli ${ }^{2,4}$ and A.J. Prioli ${ }^{2}$ \\ ${ }^{1}$ Universidade Católica de Brasília, Campus I, Brasília, DF, Brasil \\ ${ }^{2}$ Núcleo de Pesquisas em Limnologia Ictiologia e Aquicultura, \\ Universidade Estadual de Maringá, Maringá, PR, Brasil \\ ${ }^{3}$ Universidade Tecnológica Federal do Paraná, Toledo, PR, Brasil \\ ${ }^{4}$ Departamento de Biotecnologia, Genética e Biologia Celular, \\ Universidade Estadual de Maringá, Maringá, PR, Brasil
}

Corresponding author: A.J. Prioli

E-mail: ajprioli@nupelia.uem.br

Genet. Mol. Res. 14 (4): 15356-15364 (2015)

Received December 18, 2014

Accepted May 28, 2015

Published November 30, 2015

DOI http://dx.doi.org/10.4238/2015.November.30.13

\begin{abstract}
The genetic relationships among 17 species of Astyanax from the Iguaçu River and adjacent river basins in Brazil were examined using nucleotide sequences of the mitochondrial cytochrome b gene $(c y t b)$. Congruent trees were constructed using neighborjoining, maximum-likelihood, and Bayesian methods. The resulting clades suggest that at least three major groups share similar origins with the endemic species of the Iguaçu River. The results indicate that Astyanax is polyphyletic in this location, which suggests that Astyanax did not diversify from a single ancestral group that was isolated when the Iguaçu River basin formed. Astyanax bifasciatus shares an origin with some species of the altiparanae-bimaculatus complex, while $A$. minor originated from the same group as $A$. aff. paranae, $A$. fasciatus, and $A$. bockmanni. The third group includes $A$. dissimilis, Astyanax sp $\mathrm{F}$, and $A$. serratus that are endemic species to the Iguaçu River basin.
\end{abstract}


Geological and hydrological events that influenced the biogeographical patterns of these species are discussed.

Key words: Biogeography; Cytochrome b; Endemism

\section{INTRODUCTION}

The Iguaçu River in Brazil is geologically ancient, and originated during the Tertiary Period (Petri and Fulfaro, 1983). It is characterized by cataracts and waterfalls that alternate with wide meandering sections and extensive floodplains (Ministério das Minas e Energias, 1990). It contains fewer fish than the Paraná River (Garavello et al., 1997) because of its topography, as the waterfalls prevent fish migration.

The ichthyofauna of the Iguaçu River has a unique evolutionary history, with high rates of endemism; almost $80 \%$ of the fish species present are exclusively found in this hydrographical basin (Agostinho and Gomes, 1997). After the formation of the Iguaçu Falls (that are $70 \mathrm{~m}$ in height) about 22 million years ago during the Miocene Period, fish populations in the Iguaçu River basin were isolated from those in the Paraná River basin (Maack, 1981). This event triggered speciation, which resulted in a considerable amount of endemism (Kantek, 2005).

Astyanax Baird and Girard, 1854, is considered Incertae sedis, and is one of the most common and diverse genera in the Characidae family. Astyanax species occur from Texas, USA, to northeastern Argentina, and approximately 100 species occur within Brazilian hydrographical basins (Garutti and Britski, 2000; Lima et al., 2003). In Brazil they are known as "lambari" or "piaba", and inhabit different environments, including headwaters, streams, and rivers. According to the Catalog of Fishes, Astyanax contains 144 valid species (Eschmeyer, 2014). In a detailed survey of the ichthyofauna of the lower Iguaçu River, Baumgartner et al. (2012) confirmed that there is a high proportion of endemic species. Nine valid species of Astyanax, and two possible new species, were recorded. Except for Astyanax altiparanae, which may have been introduced (Prioli et al., 2002), all of the Astyanax species found here are endemic to the Iguaçu River.

The present study investigated the genetic relationships between endemic species of Astyanax from the Iguaçu River basin and species of Astyanax from the upper Paraná, Paraguay, and Doce River basins. The objective was to verify the hypothesis that Astyanax species that are endemic to the Iguaçu River do not share a single, common ancestral group.

\section{MATERIAL AND METHODS}

\section{Fish sampling}

Figure 1 shows the four river basins and locations where the Astyanax species were collected from. The species were sampled in the Iguaçu, upper Paraná, Paraguay, and Doce River basins. The samples included two groups of Astyanax species that are present in basins adjacent to the Iguaçu River basin (Table 1). The altiparanae-bimaculatus complex has already been studied from a molecular perspective (Prioli et al., 2012; Deprá et al., 2014), as has the fasciatus group (Pazza et al., 2007). We also studied five species that are endemic to the Iguaçu River basin. 


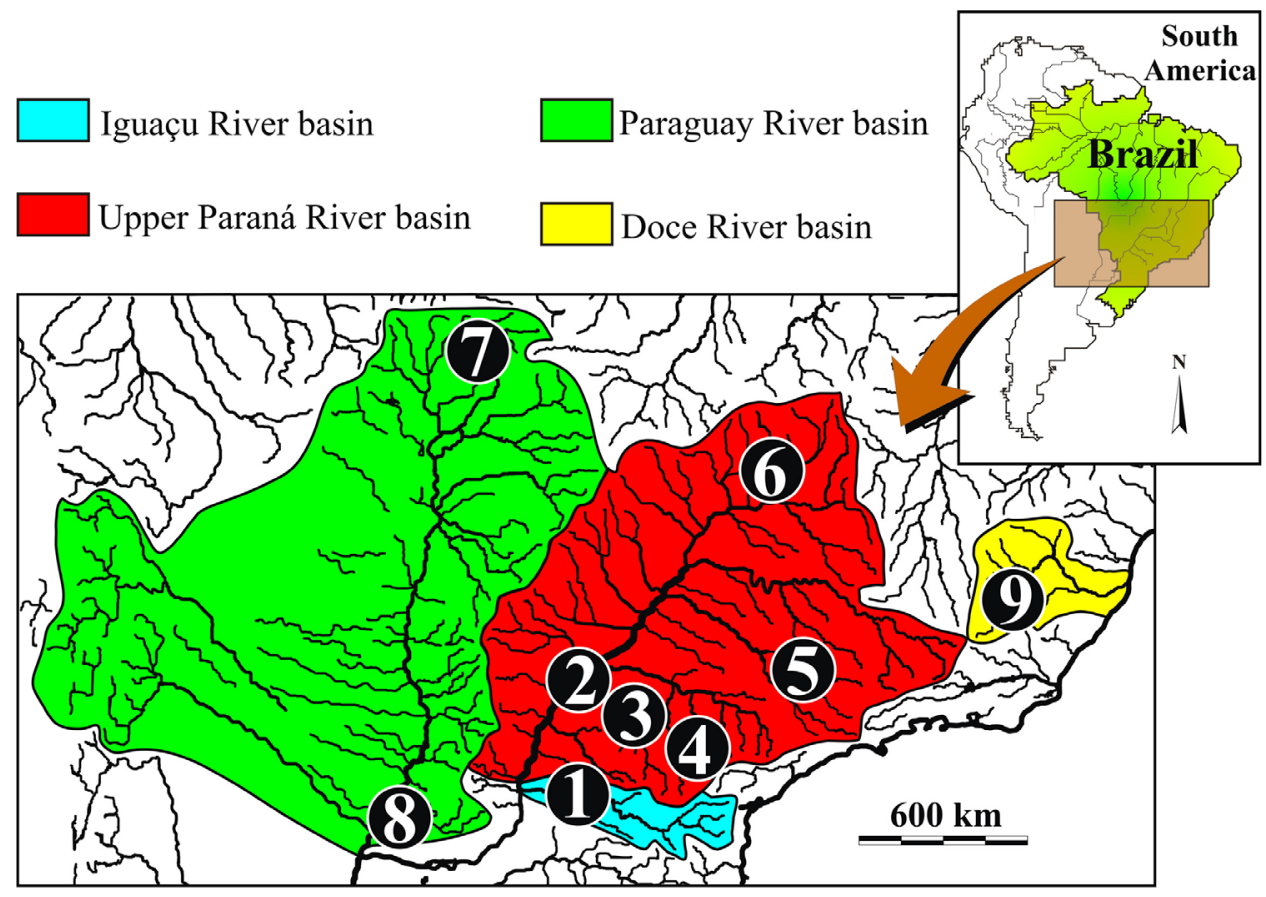

Figure 1. Astyanax sampling locations. 1) Lower Iguaçu River basin $\left(25^{\circ} 45^{\prime} \mathrm{S}, 52^{\circ} 12^{\prime} \mathrm{W}\right.$ to $\left.\left.25^{\circ} 30^{\prime} \mathrm{S}, 53^{\circ} 25^{\prime} \mathrm{W}\right) ; 2\right)$ Floodplain of the upper Paraná River $\left(22^{\circ} 47^{\prime} \mathrm{S}, 53^{\circ} 19^{\prime} \mathrm{W}\right)$; 3) Keller Stream, a tributary of the Ivaí River $\left(23^{\circ} 20^{\prime} \mathrm{S}\right.$, $\left.51^{\circ} 51^{\prime} \mathrm{W}\right)$; 4) Pitangui Stream, a tributary of the Tibagi River $\left(25^{\circ} 01^{\prime} \mathrm{S}, 50^{\circ} 04^{\prime} \mathrm{W}\right)$; 5) Passa Cinco Stream, in the Tietê River basin $\left(22^{\circ} 25^{\prime} \mathrm{S}, 47^{\circ} 42^{\prime} \mathrm{W}\right)$; 6) Lazinho Stream, in the Paranaíba River basin $\left(17^{\circ} 59^{\prime} \mathrm{S}, 48^{\circ} 38^{\prime} \mathrm{W}\right)$; 7) Cuiabá River, a tributary of the Paraguay River $\left(14^{\circ} 49^{\prime} \mathrm{S}, 56^{\circ} 24^{\prime} \mathrm{W}\right) ; 8$ ) Yacaré Stream, a tributary of the Paraguay River ( $\left.26^{\circ} 39^{\prime} \mathrm{S}, 5^{\circ} 05^{\prime} \mathrm{W}\right)$; 9) Santo Antônio Stream, in the Doce River basin $\left(20^{\circ} 50^{\prime} \mathrm{S}, 42^{\circ} 52^{\prime} \mathrm{W}\right)$.

Table 1. Sampling locations or GenBank accession numbers of Astyanax in Brazilian river basins.

\begin{tabular}{lll}
\hline River basin & Species & Location/GenBank accession number \\
\hline Lower Iguaçu & A. bifasciatus & Iguaçu River \\
& A. dissimilis & Iguaçu River \\
A. minor & Iguaçu River \\
A. serratus & Iguaçu River \\
Astyanax sp F & Iguaçu River \\
Upper Paraná & A. altiparanae & Pitangui Stream \\
& A. bockmanni & Lazinho Stream \\
& A. fasciatus & Pitangui Stream \\
& A. aff. paranae & Keller Stream \\
& Moenkhausia aff. intermedia & Floodplain \\
Astyanax sp 1 & Pitangui Stream \\
Paraguay & Astyanax sp 2 & Passa Cinco Stream \\
& Astyanax sp 4 & Pitangui Stream \\
A. abramis & Cuiabá River and Yacaré Stream \\
Doce & A. asuncionensis & Cuiabá River \\
Central America & Astyanax sp 3 & Cuiabá River \\
& A. aff. bimaculatus & Santo Antônio Stream \\
& A. fasciatus & AY639088; AY639089; AY639091; AY639092
\end{tabular}


After collection, the specimens were immediately fixed in commercial ethylic alcohol and stored at $-20^{\circ} \mathrm{C}$. Morphological identification of most of the species was conducted following the methodology of Severi and Cordeiro (1994), Garavello et al. (1997), Ingenito et al. (2004), Britski et al. (2007), and Graça and Pavanelli (2007) in the Ichthyologic Collection of the Research Nucleus in Limnology, Ichthyology, and Aquiculture of the Universidade Estadual de Maringá. Four nucleotide sequences of $A$. fasciatus and one of $A$. mexicanus from Central America (available in GenBank) were also used.

\section{Polymerase chain reaction (PCR) and sequencing}

Total DNA was extracted by the phenol/chloroform method (Oliveira et al., 2002; Panarari-Antunes et al., 2012). The cytochrome b (cytb) gene from the mitochondrial DNA region was focused and partially amplified by PCR from the total DNA using the primer pairs L14841 (5'-CCATCCAACATCTCAGCATGATGAAA-3') and H15149 (5'-CCCCTCAGAATGATATTTGTCCTCA-3'). The amplification conditions were as follows: an initial denaturation at $95^{\circ} \mathrm{C}(1 \mathrm{~min})$ followed by 35 cycles at $95^{\circ} \mathrm{C}(15 \mathrm{~s}), 53^{\circ} \mathrm{C}(30 \mathrm{~s})$, and $72^{\circ} \mathrm{C}(30 \mathrm{~s})$ for denaturation, annealing, and extension, respectively, and a final extension at $72^{\circ} \mathrm{C}(8 \mathrm{~min})$ to end the reaction. The PCR products were purified by polyethylene glycol to remove the excess primer and nucleotide residues (Rosenthal et al., 1993). The amplified fragments were then forward- and reverse-sequenced using a MegaBACE 1000 DNA Analysis System (Gel, San Francisco, CA, USA).

\section{Analyses}

All of the amplified sequences were aligned and edited by BioEdit 7.0.1 (Hall, 1999). ModelTest 3.7 (Posada and Crandall, 1998) was used to select a nucleotide substitution model from the different substitution rates that would best explain the matrix of the data produced; this was conducted in a hierarchical manner and was based on the corrected Akaike information criterion (AIC).

Three methods of phylogenetic analysis were used to identify relationships between species and to check whether there was congruence between the topologies produced by different algorithms and the criteria established for each analysis. Maximum-likelihood and neighbor-joining methods were employed using PAUP 4.0 (http://paup.csit.fsu.edu/), with 10,000 bootstrap replications. In addition, a Bayesian analysis calculated the a posteriori probabilities of the genealogical relationships, using the best evolutionary model that had been selected by ModelTest. This was conducted using MrBayes 3.0 (http://mrbayes.sourceforge. net/); the first 20,000 generations were discarded with the burn-in option, and the last 280,000 generations were used. An agreement criterion of over $50 \%$ was used to retain branches of the trees produced.

All of the phylogenetic analyses used Moenkhausia aff. intermedia as an outgroup to root and polarize the trees, because it is phylogenetically close to Astyanax (Calcagnotto et al., 2005). Nucleotide-based frequencies, transition numbers, and transversions between specimens, as well as genetic distances between the generated groups, were obtained using MEGA 5.0 (Tamura et al., 2011). 


\section{RESULTS}

A 308-bp fragment of cytb was generated for each specimen. Two hundred aligned and edited base pairs were analyzed because of the high confidence percentage (absence of ambiguous and doubtful sites) in the interval. The Tamura-Nei nucleotide substitution model $(\mathrm{TrN}+\mathrm{I})$ was the most effective in assessing the genetic relationships between species of Astyanax $(-\operatorname{lnL}=1,008.1279, \mathrm{AICc}=2,290.8320)$. The nucleotide base frequencies were $\mathrm{A}=$ $0.2743, \mathrm{C}=0.2862, \mathrm{G}=0.1473$, and $\mathrm{T}=0.2922$. The proportion of invariable sites was 0.5032 , the transition/transversion ratio rates were $\mathrm{K}_{1}=0.34$ (purines) and $\mathrm{K}_{2}=16.23$ (pyrimidines), and the general transitions/transversions ratio $\left(\mathrm{R}-\left[\left\{\mathrm{Ax} \mathrm{Gx} \mathrm{K}_{1}\right\}+\left\{\mathrm{Tx} \mathrm{Cx} \mathrm{K}_{2}\right\}\right] /[\mathrm{A} / \mathrm{G}] \mathrm{x}\right.$ $[\mathrm{T} / \mathrm{G}])$ was 4.41 .

The trees generated by the neighbor-joining (Figure 2A), maximum-likelihood (Figure 2B), and Bayesian algorithms (Figure 3) were congruent. The tree generated by Bayesian inference (Figure 3) demonstrated a posteriori probability rates of over $97 \%$ in the branches that support the most pertinent clades.

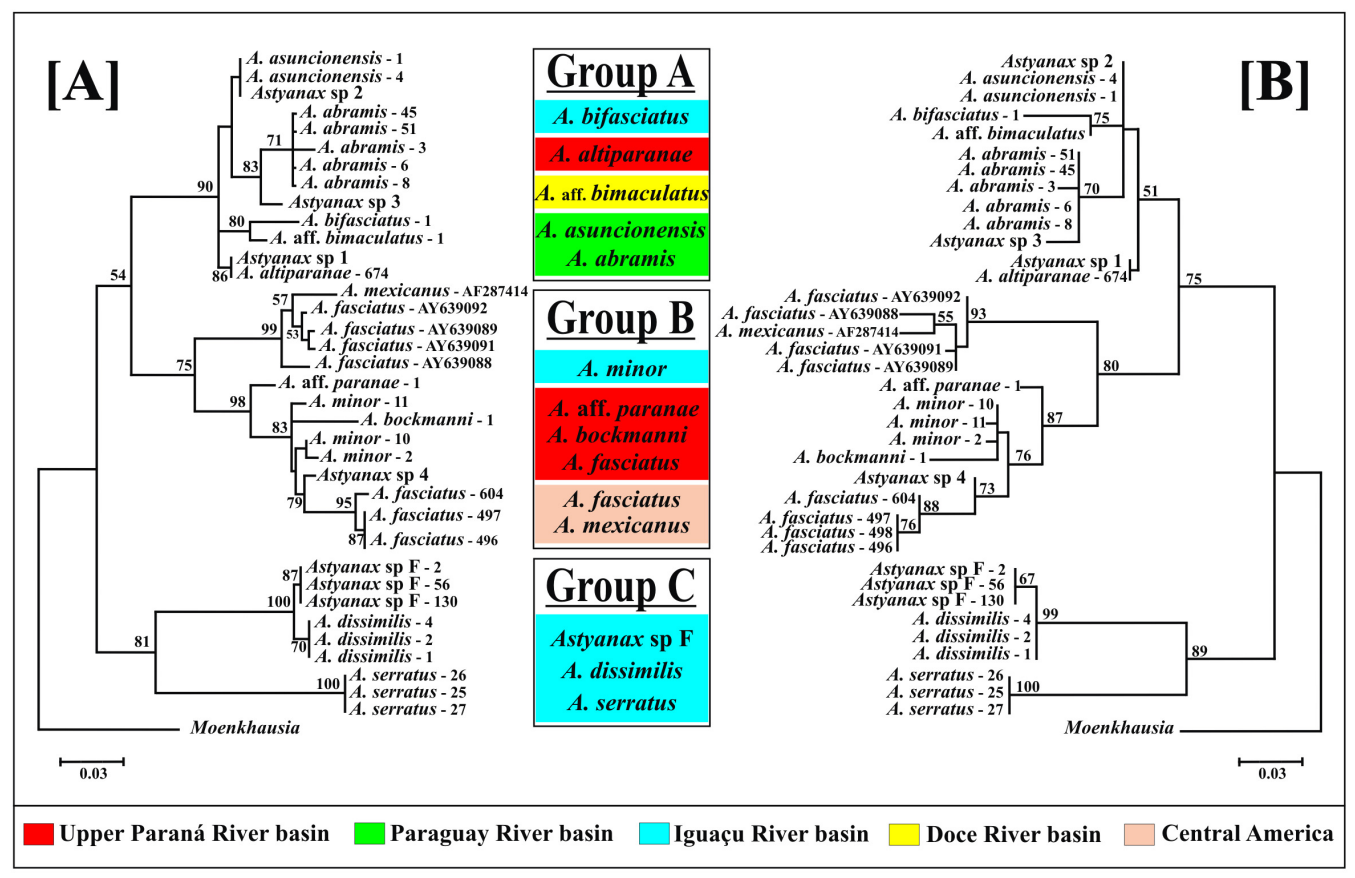

Figure 2. Neighbor-joining (A) and maximum-likelihood (B) trees generated from partial sequences of the cytochrome $b$ gene and the Tamura-Nei model. Bootstrap values $(10,000$ replications) are presented in the clade branches.

Three major clades with high support indices were identified in the trees, and were named Group A, Group B, and Group C. All of the groups contained at least one species that is endemic to the Iguaçu River basin. A. bifasciatus is in the clade that included species of the altiparanae-bimaculatus complex: A. aff. bimaculatus, A. altiparanae, A. asuncionensis, 
and A. abramis (Group A). The endemic species A. minor shared Group B with A. fasciatus, A. mexicanus, A. aff. paranae, and A. bockmanni. These species in Group B, or the fasciatus complex, are clearly distinguishable from species in Group A, or the altiparanae-bimaculatus complex. Groups A and B included species of the Iguaçu basin and of the other basins. In contrast, Group C only included species that are endemic to the Iguaçu River: A. serratus, $A$. dissimilis, and Astyanax sp F.

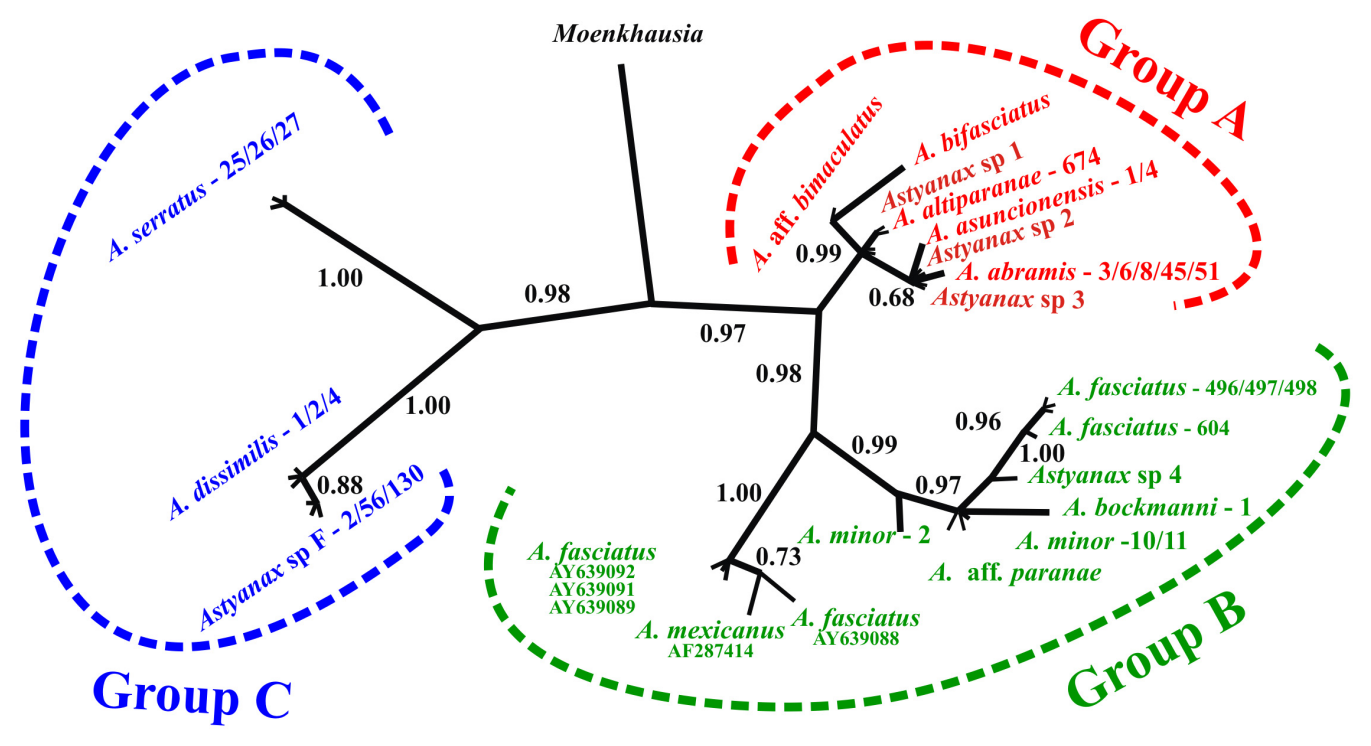

Figure 3. Bayesian tree generated from the Tamura-Nei model $(\mathrm{TrN}+\mathrm{I})$. Branch rates correspond to the percentage of a posteriori probabilities of the last 280,000 simulated generations.

Genetic distances within and between the groups were determined by the TamuraNei model (Table 2), which quantified differences between the three clades (Figures 2 and 3). The average distances within the groups are shown in the diagonal line of the distance matrix (Table 2). Group A had the lowest variation, with an average distance of 0.023 . The greatest distance within the groups was 0.070 in Group C. Group B exhibited variation similar to that in Group C, with a distance of 0.064. Distances between groups were almost two times higher than those found within groups, and ranged from 0.122 between Groups A and B to 0.185 between Groups B and C.

\begin{tabular}{|c|c|c|c|}
\hline & Group A & Group B & Group C \\
\hline Group A & 0.023 & - & - \\
\hline Group B & 0.122 & 0.064 & - \\
\hline Group C & 0.159 & 0.185 & 0.070 \\
\hline
\end{tabular}




\section{DISCUSSION}

The origin of Astyanax species that are endemic to the Iguaçu River basin appears to be related to geological events that changed the regional topography. The Iguaçu Falls is the most obvious of the many barriers along the Iguaçu River, and isolated its fish fauna about 22 million years ago during the Miocene Period (Maack, 1981). Active tectonic areas that emerged less than 1.6 million years ago (Saadi, 1993) would have distributed the ichthyologic fauna of the centralsouthern basins by coastal drainage, particularly in areas that contain the sources of the rivers Ribeira do Iguape, Iguaçu, Paranapanema, and segments of the upper Tietê River.

Another relevant geological characteristic of southeastern Brazil is the Ponta Grossa Arch, which is an emergence of the crystalline basement of the southeastern segment of the Paraná River basin (Petri and Fulfaro, 1983). This feature increases water flow between adjacent drainage systems, and consequently increases fish movement between them. Vertical movements of fractured rock and water erosion may explain the ichthyological exchanges that occurred between the Ribeira do Iguape River and the Iguaçu and Paranapanema Rivers (Ribeiro, 2006).

Although we did not study all of the species of this genus, our results are informative concerning the origin of Astyanax species in the Iguaçu River basin. The phylogenetic trees and distances obtained from the $c y t b$ sequence were consistent in revealing that the species studied are organized into three genetically distinct clades. In addition, species that are endemic to the Iguaçu River basin are represented in all three groups.

Although it is considered hypervariable, the D-loop mitochondrial sequence generates trees that are consistent in their structures (Oliveira et al., 2006; Bignotto et al., 2009; PanarariAntunes et al., 2010). However, the D-loop region is not suitable for the comparative analysis of highly differentiated species of some groups of fish, as is the case within the genus Astyanax. Astyanax species endemic to the Iguaçu River basin are genetically distant from each other, and there are a large number of gaps in their D-loop sequence alignments, which renders them a poor source of phylogenetic information (Prioli AJ, Prioli LM and Prioli SMAP, unpublished data). This may be the reason that the results obtained in the present study with $c y t b$ disagree with the D-loop topology obtained by Pie et al. (2009).

Our results strongly suggest that the endemic species Astyanax sp F, A. bifasciatus, $A$. minor, A. serratus, and A. dissimilis did not diversify from a single ancestor that had become isolated during the formation of the basin. On the contrary, they suggest that at least three ancestral groups were isolated during its formation.

This study contributes towards our knowledge of the relationships between species, and of the origin, of Astyanax in the Iguaçu River. Several approaches are needed to understand fish speciation in the Iguaçu River. Future studies should test other hypotheses using molecular markers, low-cost DNA sequencing, and robust statistical analyses (such as coalescence genealogy analysis and molecular dating), in order to investigate species population structure, cryptic diversity within species, patterns of gene flow, population divergence, and species delimitation.

\section{ACKNOWLEDGMENTS}

The authors would like to thank H.V. Alcaraz, C.S. Pavanelli, and W.J. Graça for assistance with species identification, NUPELIA-UEM for logistical support, and CNPqPELD (site 6), Furnas Centrais Elétricas, and CAPES for financial support. 


\section{REFERENCES}

Agostinho AA and Gomes LC (1997). Manejo e monitoramento de recursos pesqueiros: perspectivas para o reservatório de Segredo. In: Reservatório de Segredo: Bases Ecológicas para o Manejo (Agostinho AA and Gomes LC, eds.). EDUEM, Maringá, 319-364.

Baumgartner G, Pavanelli CS, Baumgartner D, Bifi AG, et al. (2012). Peixes do baixo rio Iguaçu. EDUEM, Maringá.

Bignotto TS, Prioli AJ, Prioli SMAP, Maniglia TC, et al. (2009). Genetic divergence between Pseudoplatystoma corruscans and Pseudoplatystoma reticulatum (Siluriformes: Pimelodidae) in the Paraná River Basin. Braz. J. Biol. 69: 681-689.

Britski HA, Silimon KZS and Lopes BS (2007). Peixes do Pantanal. Manual de identificação. Embrapa Informação Tecnológica, Brasília.

Calcagnotto D, Schauefer SA and DeSalle R (2005). Relationship among characiform fishes inferred from analysis of nuclear and mitochondrial gene sequences. Mol. Phylogenet. Evol. 36: 135-153.

Deprá IC, Gomes VN, Deprá GC, Oliveira IJ, et al. (2014). Molecular study of Astyanax altiparanae (Osteichthyes, Characidae) as a probable species complex. Genet. Mol. Res. 13: 6015-6026.

Eschmeyer WN (2014). Catalog of Fishes. California Academy of Sciences. Available at [http://research.calacademy.org/ research/ichthyology/catalog/fishcatmain.asp]. Accessed December 10, 2014.

Garavello JC, Pavanelli CS and Suzuki HI (1997). Caracterização da ictiofauna do rio Iguaçu. In: Reservatório de Segredo: bases ecológicas para o manejo (Agostinho AA and Gomes LC, eds.). EDUEM, Maringá, 61-84.

Garutti V and Britski HA (2000). Descrição de uma espécie nova de Astyanax (Teleostei: Characidae) da bacia do alto Rio Paraná e considerações sobre as demais espécies do gênero na bacia. Comum. Mus. Cienc. Tecnol. PUCRS Ser. Zool. 13: 65-88.

Graça WJ and Pavanelli CS (2007). Peixes da planície de inundação do alto rio Paraná e áreas adjacentes. EDUEM, Maringá.

Hall TA (1999). BioEdit: a user-friendly biological sequence alignment editor and analysis program for Windows 95/98/ NT. Nucleic Acids Symp. Ser. 41: 95-98.

Ingenito LFS, Duboc LF and Abilhoa V (2004). Contribuição ao conhecimento da ictiofauna da bacia do alto rio Iguaçu, Paraná, Brasil. Arq. Cienc. Vet. Zool. UNIPAR 7: 23-36.

Kantek DLZ (2005). Estudo citogenético comparativo entre populações de uma espécie de Astyanax (Characidae, Tetragonopterinae) endêmica do rio Iguaçu. Master's thesis, Universidade Federal do Paraná, Curitiba.

Lima FCT, Malabarba LR, Buckup PA, Silva JFP, et al. (2003). Genera Incertae sedis in Characidae. In: Checklist of the freshwater fishes of South and Central America (Reis RE, Kullander SO and Ferraris CJ Jr, eds.). EDIPUCRS, Porto Alegre, 106-168.

Maack V (1981). Geografia física do Estado do Paraná. Livraria José Olympio, Rio de Janeiro.

Ministério das Minas e Energias (MME) (1990). Diagnóstico e Planejamento da Utilização dos Recursos Hídricos da Bacia do Iguaçu. Companhia de Pesquisa de Recursos Minerais 1: 33.

Oliveira AV, Prioli AJ, Prioli SM, Pavanelli CS, et al. (2002). Diversity and genetic distance in populations of Steindachnerina in the upper Paraná river floodplain of Brazil. Genetica 115: 259-267.

Oliveira AV, Prioli AJ, Prioli SMAP, Bignotto TS, et al. (2006). Genetic diversity of invasive and native Cichla (Pisces: Perciformes) populations in Brazil with evidence of interspecific hybridization. J. Fish Biol. 69: 260-277.

Panarari-Antunes RS, Gomes VN, Prioli SMAP, Prioli RA, et al. (2010). Molecular characterization and phylogenetic relationships among species of the genus Brycon (Characiformes: Characidae) from four hydrographic basins in Brazil. Genet. Mol. Res. 9: 674-684.

Panarari-Antunes RS, Prioli AJ, Prioli SMAP, Gomes VN, et al. (2012). Genetic divergence among invasive and native populations of Plagioscion squamosissimus (Perciformes, Sciaenidae) in Neotropical regions. J. Fish Biol. 80: 24342447.

Pazza R, Kavalco KF, Prioli SMAP, Prioli AJ, et al. (2007). Chromosome polymorphism in Astyanax fasciatus (Teleostei, Characidae), Part 3: Analysis of the RAPD and ISSR molecular markers. Biochem. System. Ecol. 35: 843-851.

Petri S and Fulfaro VJ (1983). Geologia do Brasil. Edusp, São Paulo.

Pie MR, Baggio RA, Boeger WA, Patella LA, et al. (2009). Molecular data reveal a diverse Astyanax species complex in the upper Iguaçu River. J. Fish Biol. 75: 2357-2362.

Posada D and Crandall KA (1998). MODELTEST: testing the model of DNA substitution. Bioinformatics 14: 817-818.

Prioli AJ, Carlo VA, Soria TV, Prioli SMAP, et al. (2012). Mitochondrial D-loop nucleotide diversity in Astyanax (Osteichthyes, Characidae) from the upper Paraná and upper Paraguay River basins. Genet. Mol. Res. 11: 1064-1074.

Prioli SMAP, Prioli AJ, Júlio Jr HF, Pavanelli CS, et al. (2002). Identification of Astyanax altiparanae (Teleostei, Characidae) in the Iguaçu River, Brazil, based on mitochondrial DNA and RAPD markers. Genet. Mol. Biol. 25: 
421-430.

Ribeiro AC (2006). Tectonic history and the biogeography of the freshwater fishes from the coastal drainages of eastern Brazil: an example of fauna evolution associated with a divergent continental margin. Neotrop. Ichthyol. 4: 225-246.

Rosenthal A, Coutelle O and Craxton M (1993). Large-scale production of DNA sequencing templates by microtitre format PCR. Nucleic Acids Res. 21: 173-174.

Saadi A (1993). Neotectônica da plataforma brasileira: esboço e interpretações preliminares. Geonomos 1: 1-15.

Severi W and Cordeiro AAM (1994). Catálogo de peixes da bacia do rio Iguaçu. IAP/GTZ, Curitiba.

Tamura K, Peterson D, Peterson N, Stecher G, et al. (2011). MEGA5: Molecular evolutionary genetics analysis using maximum likelihood, evolutionary distance, and maximum parsimony methods. Mol. Biol. Evol. 28: 2731-2739. 